\title{
PROGRAM BIMBINGAN PRIBADI SOSIAL UNTUK MENINGKATKAN DISIPLIN SISWA DI SEKOLAH SISWA SMA NEGERI 1 DENPASARKELAS X MIA 11 SEMESTER GENAP TAHUN PELAJARAN 2016/2017
}

\author{
Jarwati \\ SMA Negeri1 Denpasar \\ Email:drajarwati@yahoo.co.id
}

\begin{abstract}
ABSTRAK
Penelitian ini bertujuan untuk mengetahui apakah program bimbingan pribadi social dapat meningkatkan disiplin siswa kelas X MIA 11 semester genap di SMA Negeri 1 Denpasar pada tahun pelajaran 2016/2017. Metode pengumpulan datanya adalah dokumentasi, observasi dan catatan harian. Data penelitiandianalisisdenganmetodeanalisisdeskriptif. Teknik ini dianggap tepat karena untuk anak SMA masih perlu diarahkan karena kekurangan pengalaman hidup dalam mengambil suatu keputusan atau kebijaksanaan dan dalam pergaulan social baik di lingkungan sekolah maupun luar sekolah. Hasil yang diperoleh dari penelitian ini menunjukkan bahwa pada awalnya memperoleh nilai rata-rata 58,38 berada pada kategori kurang dan pada siklus I naik menjadi kategori cukup dengan nilai rata-rata 73,80 serta pad asiklus II naik menjadi kategori baik dengan nilai rata-rata 90,33. Kesimpulan yang diperoleh dari penelitian ini adalah program bimbingan pribadi social dapat meningkatkan kedisiplinan siswa kelas X MIA 11 semester genap di SMA Negeri 1 Denpasar pada tahun pelajaran 2016/2017.
\end{abstract}

Kata Kunci : program, bimbinganpribadisosial, disiplin

\begin{abstract}
This study aims to find out whether the social personal guidance program can improve the discipline of students in class X MIA11 even in the SMA 1 Denpasar in the 2016/2017 school year. The data collection methods are documentation, observation and diary. The research data were analyzed by descriptive analysis method. This technique is considered appropriate because high school students still need to be directed because of a lack of life experience in making a decision or wisdom and in social interaction both in the school environment and outside the school. The results obtained from this study indicate that initially obtained an average value of 58.38 in the less category and in the first cycle it rose to a sufficient category with an average value of 73.80 and in the second cycle it rose to a good category with an average value average of 90.33. The conclusion obtained from this study is that the social personal guidance program can improve the discipline of students of class X MIA 11 even semester at SMA 1 Denpasar in the 2016/2017 school year.
\end{abstract}

Keywords: Program, Personal Social Guidance, Discipline

\section{PENDAHULUAN}

Siswa pada usia Sekolah Menengah Atas merupakan generasi muda yang berada pada tahap perkembangan remaja awal yaitu antara usia 13-17 (Hurlock,1992:206). Pada masa remaja awal ditandai oleh sifat-sifat negatif pada remaja sehingga seringkali masa ini disebut masa negatif dengan gejalanya seperti tidak tenang, kurang suka bekerja dan pesimis. Secara garis besar, sifat-sifat negatif itu dapat diringkas, yaitu a) negatif dalam prestasi, baik prestasi jasmani maupun prestasi mental; b) negatif dalam sikap 
sosial, baik dalam bentuk menarik diri maupun agresif terhadap masyarakat / negatif aktif (Yusuf, 2004:26). Dari penjelasan tersebut dapat diambil kesimpulan bahwa remaja adalah individu yang cenderung banyak melakukan hal negatif, hal tersebut menandakan remaja senantiasa terlena dengan dunianya, merekaterkadang kurang peduli terhadap tuntutan dari lingkungan yang mengharuskan mereka mengikuti norma yang berlaku dan bertanggung jawab terhadap perilaku yang remaja perbuat.

Remaja juga terkadang menuntut untuk mendapatkan hak yang selayaknya, tanpa menghiraukan kewajiban yang harus mereka lakukan. Seperti hal nya di sekolah, remaja (siswa) belum sepenuhnya melaksanakan kewajiban sebagai seorang siswa, terutama dalam menaati aturan tata tertib yang berlaku di sekolah. Aturan-aturan yang berkembang sudah sewajarnya ditaati dengan baik oleh siswa. Seperti yang telah dijelaskan dalam dalam UU Sistem Pendidikan Nasional No. 20 Th 2003 Bab V Pasal 12 Ayat (2) yang menyatakan bahwa, "Setiap peserta didik berkewajiban menjaga normanorma pendidikan untuk menjamin keberlangsungan proses dan keberhasilan pendidikan". Dalam Undang-Undang tersebut dijelaskan bahwa sudah menjadi kewajiban siswa sebagai peserta didik untuk menjaga norma- norma pendidikan dengan cara menaati peraturan yang ada disekolah. Tumbuhnya kesadaran siswa dalam menaati norma atau aturan yang berlaku akan dapat menciptakan suasana sekolah yang kondusif. Kesadaran siswa dalam mengatur diri dan menaati peraturan atau norma yang berlaku tersebut disebut dengan disiplin (Yusuf, 1989:28).

Setiap individu (siswa) membutuhkan kedisiplinan karena dengan disiplin individu siswa dapat berperilaku tidak menyimpang, dengan disiplin individu dapat memahami dan menyesuaikan diri dengan tuntutan lingkungan, dapat mengatur keseimbangan keinginan individu satu dengan individu lainnya, menjauhi siswa melakukan hal-hal yang dilarang sekolah, mendorong siswa melakukan hal-hal yang baik dan benar (Rachman, dalam Tulus :171-172). Yusuf (1989:44) mengungkapkan bahwa dengan disiplin anak dapat memahami batas-batas norma dan mampu berperilaku sesuai dengan batasan norma tersebut, dengan kata lain anak dapat mengendalikan diri dari perilaku yang menyimpang. Sedangkan Unaradjan (2003:13-14) mengungkapkan bahwa disiplin dapat membantu individu untuk mendapatkan penerimaan social dandisiplin merupakan hal penting bagi keberhasilan penyesuaian diri.

Meskipun disiplin berdampak positif bagi kehidupan dan perilaku siswa, akan tetapi pada kenyataannya masih banyak siswa yang kurang memperhatikann kedisiplinan. Ketidakdisiplinan siswa merupakan suatu masalah pada kebanyakan sekolah, hal tersebut dapat dilihat dari berbagai pelanggaran aturan dan tata tertib sekolah yang dilakukan siswa, seperti: masih banyak siswa yang terlambat datang ke sekolah, siswa terlambat masuk kelas, sering membolos dari sekolah, makan di kelas pada saat mengikuti pelajaran, merusak fasilitas sekolah, corat-coret tembok di lingkungan sekolah, membuat 
kegaduhan saat jam pelajaran berlangsung, mengobrol pada saat upacara, berpakaian seragam tanpa atribut yang lengkap, tidak peduli terhadap kebersihan dan keindahan lingkungan sekolah seperti mencorat- coret dinding sekolah atau fasilitas sekolah, pertikaian antar siswa. Oleh karena itu, siswa perlu ditanamkan kedisiplinan dalam diri siswa agar terciptalah siswa yang tidak hanya berprestasi akademik namun juga berakhlak serta memiliki pengendalian diri yang baik.

Dari hasil pengamatan penulis yang dilakukan di SMA Negeri 1 Denpasar pada bulan Januari ditemukan beberapa fenomena pelanggaran disiplin, seperti: penampilan siswa yang tidak sesuai dengan peraturan sekolah (berpakaian tidak rapih dan lengkap), mengobrol saat guru menerangkan, membaca buku pada saat guru menerangkan, bermain handphone di kelas pada saat jam pelajaran, pergi ke kantin pada saat jam pelajaran berlangsung, terlambat datang kesekolah. Perilaku- perilaku tersebut cenderung pada perilaku yang tidak sesuai dan menyimpang dari peraturan yang telah dibuat oleh sekolah.Sesuai dengan yang dikemukakan oleh Yusuf (1989) ketidakdisiplinan siswa merupakan permasalahan yang harus segera dipecahkan karena kedisiplinan siswa merupakan masalah yang besar setelah masalah pribadi. Bimbingan dan konseling sebagai suatu sub sistem sekolah memiiki peran penting dalam mendukung pencapaian proses pembelajaran dengan memfasilitasi siswa agar mampu mencapai perkembangannya dengan optimal. Salah satu perkembangan yang harus dicapai siswa di sekolah yaitu perkembangan pribadi social terutama dalam meningkatkan kedisiplinan. Layanan bimbingan dan konseling diharapkan dapat memberikan kontribusinya untuk meningkatkan disiplin siswa di sekolah, sehingga pada akhirnya siswa mampu berdisiplin dimanapun siswa tersebut berada. Terlebih lagi keberadaan layanan bimbingan dan konseling dalam setting pendidikan telah memiliki legalitas yang cukup kuat. Penegasan tentang posisi bimbingan dan konseling dalam seting pendidikan formal tertulis dalam Undang-Undang Republik Indonesia nomor 20 tahun 2003 tentang Sistem Pendidikan Nasional. Pada Bab I Pasal 1 ayat (4) yang menyatakan bahwa: Pendidik adalah tenaga kependidikan yang berkualifikasi sebagai guru, dosen, konselor, pamong belajar, widyaiswara, tutor, instruktur, fasilitator dan sebutan lain yang sesuai dengan kekhususannya yang berpartisipasi dalam penyelenggaraan pendidikan.

Dalam Undang-Undang tersebut tercantum konselor, di mana konselor adalah orang yang memiliki kemampuan dan kewenangan untuk melaksanakan layanan bimbingan dan konseling. Bimbingan dan konseling adalah upaya yang dilakukan oleh konselor untuk mengatasi berbagai permasalahan yang dihadapi oleh siswa salah satunya permasalahan ketidakdisiplinan siswa. Berdasarkan permasalahan-permasalahan mengenai kedisiplinan siswa, kiranya diperlukan program bimbingan untuk meningkatkan disiplin siswa yang disusun secara sistematis, terarah, dan terpadu dan hendaknya dikembangkan sesuai dengan kebutuhan siswa, sekolah, dan tidak 
melenceng dari tujuan pendidikan. Bentuk bimbingan yang dirasa tepat diberikan untuk membantu permasalahan disiplin siswa ialah bimbingan pribadi-sosial karena permasalahan disiplin sangat erat kaitannya dengan masalah individu dalam diri siswa dan individu dengan lingkungannya yang termasuk kedalam masalah pribadi-sosial. Bimbingan pribadi sosial diarahkan untuk

memantapkan kepribadian dan mengembangkan kecenderungan siswa dalam menangani masalah-masalah dalam dirinya yang meliputi masalah hubungan sosial dengan sesama teman, cara pribadi berperilaku dalam kehidupan sosial yang lebih luas, menerapkan nilai dan cara berperilaku sosial dalam kehidupan sosial yang lebih luas, penyelesaian konflik, serta kecenderungannya untuk mematuhi peraturan yang berlaku di sekolah (Juntika, 2007).

\section{METODE PENELITIAN}

Rancangan yang digunakan dalam penelitian ini adalah Penelitian Tindakan Kelas. Subyek penelitian adalah adalah siswa-siswa kelas X MIA 11 semester genap tahun pelajaran 2016/2017 di SMA Negeri 1 Denpasar. Obyek penelitiannya adalah peningkatan disiplin siswa di kelas X MIA11 semester genap SMA Negeri 1 Denpasar pada tahun pelajaran 2016/2017, setelah diberikan bimbingan sesuai dengan program bimbingan pribadi social.

Penelitian ini akan berlangsung dari bulan Januari sampai bulan Mei tahun 2017. Data dikumpulkan dengan metode observasi dan metode analisis data dengan teknik analisis deskriptif.
Indikator keberhasilan yang diusulkan pada penelitian ini meliputi tingkat keberhasilan per siklus pada aspek kedisiplinan siswa. Tingkat kedisiplinan siswa yang diharapkan pada siklus I mencapai rata-rata cukup dan pada siklus II mencapai nilai rata-rata baik.

\section{HASIL PENELITIAN DAN PEMBAHASAN}

Hasil penelitian menunjukkan kedisiplinan siswa pada awalnya masih rendah dengan penilaian rata-rata 58,38 atau berada pada kategori kurang (D). Pelaksanaan yang dilakukan dalam kegiatan awal diperoleh data yaitu 8 orang siswa $(22,86 \%)$ berada pada kategori sangat kurang dan 23 orang siswa atau $65,71 \%$ berada pada kategori kurang dan dan 4 orang siswa atau 11,43\% berada pada kategori cukup. Pada siklus I dari 35 siswa yang diteliti, ada 7 orang siswa atau $17,15 \%$ masih berada pada kategori kurang dan ada 20 orang siswa atau $57,14 \%$ berada pada kategori cukup serta ada 9 orang siswa atau $25,71 \%$ sudah berada pada kategori baik. Dari hasil tersebut gambaran yang dapat disimpulkan adalah masih banyak siswa yang belum mencapai penilaian sesuai harapan atau masih banyak siswa yang belum mencapai keberhasilan seperti tuntutan indikator. Selanjutnya disajikan dalam bentuk grafik sebagai berikut.

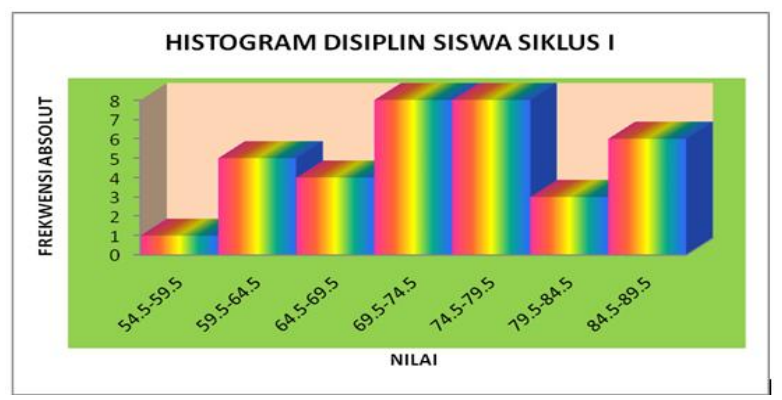


Secara kualitas semua kategori data di atas dibuat interpretasinya, pada siklus I ini kedisiplinan siswa sudah meningkat. Bila dicek hasilnya dalam bentuk nilai, maka pada siklus I ini nilai kedisipilinan siswa naik dari nilai D ke nilai $\mathrm{C}$ dengan perolehan nilai rata-rata sebesar 73,80 .

Pada siklus II dari 35 orang siswa yang diteliti ada 3 orang siswa atau $8,57 \%$ yang masih berada pada kategori cukup dan ada 11 orang siswa atau $31,43 \%$ yang berada pada kategori baik serta 21 orang siswa atau $60 \%$ berada pada kategori sangat baik. Secara kualitas semua kategori data di atas dibuat interpretasinya maka dibandingkan dengan siklus I, pada siklus II ini kedisiplinan siswa sudah meningkat. Nilai kedisiplinan siswa naik dari nilai $\mathrm{C}$ ke nilai $\mathrm{B}$ dengan perolehan nilai rata-rata sebesar 90,33. Selanjutnya disampaikan dalam bentuk grafik sebagai berikut.

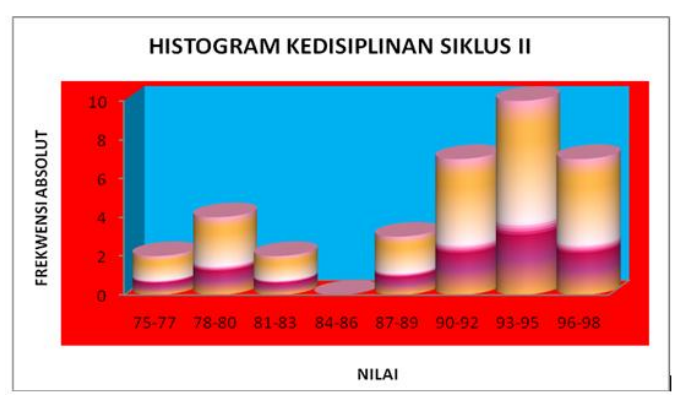

Hasil yang diperoleh ini sudah memenuhi usulan indicator keberhasilan penelitian. Oleh karenanya penelitian tidak dilanjutkan ke siklus berikutnya. Setelah diberikan bimbingan sesuai dengan program bimbingan pribadi social kedisiplinan siswa meningkat sesuai dengan harapan. Data peningkatan tersebut dapat disampaikan seperti tabel berikut

Tabel 1 Peningkatan Kedisiplinan Siswa dari Awal ke Siklus I dan ke Siklus II

\begin{tabular}{|c|c|c|c|c|c|}
\hline No & Kelas & Pengambilann Data & $\begin{array}{c}\text { Awal } \\
\text { Disiplin Siswa }\end{array}$ & $\begin{array}{c}\text { Siklus I } \\
\text { Disiplin Siswa }\end{array}$ & $\begin{array}{c}\text { Siklus II } \\
\text { Disiplin Siswa }\end{array}$ \\
\hline 11. & $\begin{array}{c}\mathrm{X} \\
\text { MIA11 }\end{array}$ & Observasi & 58,38 & 73,80 & 90,33 \\
\hline
\end{tabular}




\section{PENUTUP}

\section{Simpulan}

Sesuai dengan tujuan penelitian yaitu mencari peningkatan kedisiplinan siswa, dapat disampaikan bahwa program bimbingan pribadi social dapat meningkatkan kedisiplinan siswa. Ini terbukti dari kenaikan nilai rata-ratanya dari awal 58,38 naik menjadi 73,80 pada siklus I dan naik menjadi 90,33 pada siklus II.

\section{Saran}

Dapat disarankan bahwa model ini dapat digunakan oleh guru BK dan bagi sekolah dalam meningkatkan mutu pendidikan di sekolah khususnya layanan bimbingan dan konseling.

\section{DAFTAR PUSTAKA}

ABKIN. (2008). Rambu-Rambu Penyelenggaraan Bimbingan dan Konseling dalam Jalur Pendidikan. Bandung: ABKIN

Ardias, Puspita. (2011). Disiplin Diri Siswa Ditelaah Berdasarkan Pola Asuh Orang Tua dan Implikasinya pada Layanan Bimbingan dan Konseling. Skripsi PPBFIP UPI Bandung: Tidak diterbitkan.

Arikunto,S. (2006). Prosedur

Penelitian: Suatu Pendekatan

Praktik. Edisi Revisi VI.

Jakarta: PT Rineka Cipta

Arikunto, S. (2010). Prosedur

Penelitian: Suatu Pendekatan

Praktik. Edisi Revisi 2010.

Jakarta: PT Rineka Cipta

Astied, Putri. (2005). Kontribusi Penerapan Disiplin oleh guru Bidang Studiterhdap Disiplin diri
Siswa di Sekolah. Skripsi PPBFIP UPI Bandung: Tidak diterbitkan.

Darmajari. (2010). Program Bimbingan bagi Pengembangan Disiplin Siswa Berbasis Nilai Sholat di SMP Karangtanjung Pandeglang. Tesis Magister pada FPS FIP UPI Bandung: Tidak diterbitkan.

Departemen Pendidikan Nasional (2007). Penataan Pendidikan Profesional Konselor dan Layanan Bimbingan dan Konseling dalam .Jalur Pendidikan Formal. Bandung: Jurusan Psikologi Pendidikan FIP UPI Bandung Bekerja sama dengan PB. ABKIN.

Depdikbud. 2003. Undang-undang Republik Indonesia Nomor 20 tahun 2003 Tentang Sistem Pendidikan Nasional. Jakarta: Departemen Pendidikan Nasional.

Dewi, Anggita. (2011). Program Bimbingan Pribadi Untuk Meningkatkan Disiplin Siswa. Skripsi PPB FIP UPI Bandung: Tidak diterbitkan.

Elizabeth, Hurlock. 1997. Psikologi Perkembangan suatu pendekatan sepanjang rentang hidup. Jakarta: Erlangga.

Furqon. (2001). Statistika Terapan untuk Pendidikan. Bandung: Alfabeta. Lestari, Melina. (2006). Kontribusi Disiplin terhadap Kedisiplinan Siswadi Sekolah. Skripsi PPBFIP UPI Bandung: Tidak diterbitkan.

Lindgren, Henry. (1976). Educational Psychologyin The Classroom. Canada. Nurihsan, Juntika. (2003). Dasar-Dasar Bimbingan dan Konseling. Bandung: Mutiara.

Nurmawati, Nita. (2010). Profil Disiplin Siswa Disekolah Menengah Atas. Skripsi PPBFIP UPI Bandung: Tidak diterbitkan

Nursidik. (2007). "Perlakuan guru bimbingan dan konseling terhadap disiplin siswa. [Online].Tersedia:http://nhowitzer. multiply.com. [01 februari 2012]. 
Prayitnodan Amti, Erman.(1994). Dasardasar Bimbingan dan Konseling. Jakarta: Rineka Cipta.

Riduwan.(2006). Belajar Mudah Penelitian untuk Guru-Karyawan dan Peneliti Pemula. Bandung: Alfabeta

Rusmana, Nandang. (2009). Bimbingan dan Konseling Kelompok di Sekolah Teori dan Aplikasi. Universitas Pendidikan Indonesia.

Samidjo. (1985). Ringkasan dan Tanya Jawab Hukum Pidana. [Online]. Tersedia: www.google.com. [1 Oktober 2011]

Sudrajat, Akhmad. (2008).

Disiplin Siswa Disekolah. [Online]. Tersedia http://akhmadsudrajat.wordpress.c om/author/akhmadsudrajat/. [1 Oktober 2011] 
